\title{
RELIGIOUS ANTHROPOCENTRISM The Discourse of Islamic Psychology among Indonesian Muslim Intellectuals
}

\author{
Nur Hamim \\ IAIN Sunan Ampel, Surabaya - Indonesia
}

\begin{abstract}
Ideas in psychology are often criticized as being dominated by the spirit and the model of secular and liberal Western thinking. They are frequently deemed to bring bias when applied to analyze the psychological problems of human beings in the context of other cultures, especially in the context of Islamic culture. This paper investigates Indonesian Muslim scientists' offer of an alternative of grand theory in psychology formulated from a more balanced paradigm called religious anthropocentric psychology. Indonesian Muslim scientists develop this paradigm as an attempt to construct spiritual-religious psychology or Islamic psychology. The paper describes an increasing awareness among those Muslim scientists to develop theories of humanistic psychology with spiritual and religious values. This kind of psychological theory seems to be the basis for so-called Islamic psychology. Furthermore, in addition to its reference toward the anthropocentric paradigm, this kind of psychology also refers to the religious-Islamic values, theo-centric or Godcentric.
\end{abstract}

Keywords: Islamic psychology, Indonesian Muslim intellectuals, religious anthropocentrism, Western psychology.

\section{Introduction}

The discourse of psychology cannot be separated from three mainstreams recently recognized as an established theory of psychology, psychoanalysis by Sigmund Freud, behaviorism by JB Watson and BF Skinner, and humanism by Abraham Maslow. These three remarkable streams, irrespestive of controversies over them, yet 
still exist and even remain committed to their views. Moreover, in later development, each raises new streams in the field of psychology.

Looking at the history of emergence of the theories of psychology, those three streams cannot be detached from the growth and development of Western culture after the rising movement of Renaissance and Aufklaerung. Basically, all ideas in psychology are dominated by the spirit and the model of secular and liberal Western thinking. Therefore, they often bring bias when applied to analyze the psychological problems of human beings in the context of other cultures, especially in the context of Islamic culture. The most distinct bias can be seen in Western psychology theory that does not base its theory on spiritual-religious norms; instead, it is based on the speculative views about the human.

The criticism toward the bias of grand theory of thinking in modern Western psychology is also raised by Western scientists themselves, as expressed by Gordon Westland in his book Current Crises of Psychology. He states that the Western psychological theories experience various crises: usefulness, laboratory, philosophy, professional, publication, ethic, and resolution. ${ }^{1}$

Based on those problems, Muslim scientists are motivated to offer an alternative of grand theory in psychology which is formulated from the paradigm of Islamic Psychology. In this paper, the author tries to offer a model that can be used as a basis for the body of Islamic psychology, namely religious anthropo centric psychology paradigm.

\section{A Historical Overview of Western Psychology}

Just to gain a better undertanding of how grand theories in psychology developed, it needs to trace the roots of Western psychology back to the Greek philosophy. The word "psychology" itself is derived from the Greek words 'psyche' (lit. "soul") and 'logos' (lit. "study"). Psychology thus started as part of philosophy, and became an independent discipline in much later development.

Mind was a central issue in classical philosophy. Plato and Aristotle were among the first philosophers who developed theories and ideas about the mind. Plato, was positive in that body and mind are two separate entities, and mind could exist even after death. He, however, developed a perspective saying that education can bring changes to the

${ }^{1}$ Gordon Westland, Current Crises of Psychology (London: Heinemann Educational Books Ltd, 1978), pp. 11-16. 
basic nature of the mind. The disciple of Plato, Aristotle also promoted the concept of body-mind duality.He believed, however, that of each of these is the manifestation of the other. Furthermore, he was pessimistic about the role of education in changing the fundamental nature of humans. ${ }^{2}$

The relation between body and mind was also of important concerns of non-Greek philosophers. For example, Rene Descartesalso subscribed to the concept of body-mind duality as developed by Greek philosophers as such. He noted, however, that there is an uninterrupted transaction between the body and the mind. His background as a French philosopher and mathematician, who originated the Cartesian system of coordinates or the coordinate geometry, seems to have contributed to his ideas about the body-mind duality. ${ }^{3}$

John Locke, a British philosopher and psychologist of the eighteenth century AD, developed an idea that knowledge has a close relationship with the empirical experience, and that thinking is not innate. He argued that the mind of a newly-born child is like a cleanslate on which anything can be written. Locke further argued that knowledge occurs only when the sense organs interact with the outer world. ${ }^{4}$

One, in fact, should note that these two ideas, the body-mind duality and the 'clean-slate' mind, have been the strong roots of Western psychology for many decades. It was not until the twentieth century that several prominent Western psychologists, especially Carl Gustav Jung and Abraham Maslowattempted to break free from the tenets of these strong-held, long working concepts.

A new development took place to psychology in the twentieth century AD. Several points of evidence can be laid here. E.H. Weber, a German scientist, attempted a scientific approach in the study of the mind by his finding of the quantitative relation between stimulus intensity and the resultant sensory experience. This kind of approach

\footnotetext{
${ }^{2}$ For more information, see John Heil (ed.), Philosophy of Mind: A Guide and Anthology (Oxford; New York: Oxford University Press, 2004).

${ }^{3}$ See Rene Descartes, Descartes: Philosophical Letters, translated and edited by Anthony Kenny (Oxford, Clarendon Press, 1970).

${ }^{4}$ A good discussion about the ideas and writings of Locke can be found in Jean S. Yolton, John Locke: A Descriptive Bibliography (Bristol: Thoemmes Press, 1998).
} 
was later popular as the Weber's law. Almost in the same period, G.T. Fechner, who is called the father of quantitative psychology, coined psycho-physics which is the quantitative study of external structures and sensory experience. Then came Darwin with his revolutionary 'origin of species' which influenced psychology and human thought.

It was not until the first decade of the $20^{\text {th }}$ Century $\mathrm{AD}$ that psychology experienced new development. Ivan P. Pavlov, a Russian psychologist, made a path breaking finding when he was studying the digestion process in dogs. Before the experimental dog was given food, a bell was sounded. When this was repeated several times, the dog started salivating the very moment it heard the bell sound. Pavlov called this the conditioned reflex. This was one of the greatest findings that made radical changes in the field of psychology.

There are several remarkable schools of psychology, including Structuralism, Functionalism, Freud and Psycho Analysis, Alfred Adler and Individual Psychology, Jung and Analytical Psychology, Behaviorism, Gestalt Psychology, and Humanistic Psychology. In terms of Structuralism, Titchner and his followers said that conciseness can be analyzed into three-sensation, perception and feeling. Titchner and his followers are called structuralists and their main method for study of mind was introspection. In relation to Functionalism, William James, the father of American Psychology, J.R.Angels and John Dewey argued that psychologists should study the function of the mind and not its structure. These group of psychologists are called functionalists.

Freud and Psycho Analysis owes much to Sigmund Freud of Vienna. Considered as the father of modern psychology, he originated a new method called the Free Association Technique. Freud considered that mind has three parts-the conscious, the pre-conscious and the unconscious. He considered that $90 \%$ of the mind is the unconscious mind. He argued that $I d$ (unconscious mind) is the seat of repression, and instincts. Freud further considered that behind any behavior is the libido energy. He divided the personality into three- $i d$, ego, and superego. Of these, Id goes after pleasure and thus is said to be governed by the pleasure principle. Ego which is the organized part of Id is driven by the Reality Principle. Superego connects the id to the external world and is considered the conscience. Later, Erich Frome, Karan Horney, Erik Erikson, Harry Sullivan and Otto Rank improved upon the ideas of Frued and so they are called Neo Fruedians. 
In relation to Alfred Adler and Individual Psychology, Alfred Adler gave the focus to society because he thought that since we are social animals we should give emphasis on social factors. He argued that, the will to power and superiority are thus more important than sex or will to pleasure. So, the individual will try to overcome the deficits he has or he thinks he has. He will try to show superiority or ambition. Inferiority complex is the most important concept Adler added to psychology. His psychology is called Individual Psychology.

The so-called Jung and Analytical Psychology owes much to Carl Gustav Jung. Like Adler, he was in the psychoanalytical camp in the beginning, but later parted with Freud to create his own (school of) psychology called the Analytical Psychology. He dismissed the Freudian theory that the only motive that drive the unconscious is sex. Jung extended the concept of the unconscious beyond the individual. Thus he said that there is a collective unconscious besides the individual unconscious. He postulated that the racial memory of centuries is precipitated in the unconscious of each individual. According to him, the main ingredient of the collective unconscious is the archetype.

John B. Watson, also of America, proposed Behaviorism in psychology. He argued that psychologists as scientists should study observable human nature and not the concepts like mind and consciousness. He and his followers tried to explain behavior based on stimulus and response. They are called behaviorists and their school of psychology is called behaviorism. Tolman, Hull and B.F. Skinner are the later behaviorists. Skinner originated operant conditioning which is one of the most used techniques for psychological therapy today.

Gestalt Psychology was a reaction to the over emphasis of reductionistic methods in psychology. The gestalt psychologists were against this blind reliance on analysis and reductionism. They believed that behavior should be understood in a holistic way. Max Wertheimer, Wolfgang Kohler, Kurt Kafka were the first proponents of this school psychology.

In developing Humanistic Psychology as a school of psychology, some psychologists believed that neither Frued et al nor the behaviorists could include the complexity and uniqueness of man their studies of psychology. So a group of psychologists gave human experience more importance and they are called humanists. They argued that man is a subjective animal. The humanists counted that the 
motives for development and to become perfect are more important than sex, power etc. They brought back the dignity of man that Frued and others undignified.

They denied Freudian unconscious or behaviorstic environment as the ultimate basis of behavior and said that man is not a slave of either the unconscious or the situation. Gestalt psychology, Indian Psychology, Psychology of Consciousness, Environmental Psychology, Para Psychology are the schools of psychology that are included in Humanistic psychology. Gordon W Allport, Carl Rogers, and Abraham Maslow are some of the early proponents of humanistic psychology.

Despite the aforementioned remarkable schools of Western psychology, there are three major forces in modern Western psychology for their great influences, Freudian Psychoanalysis, behaviorism, and the Humanistic Psychology. Freudian Psychoanalysis and the offshoots from it are considered the First Force in Psychology. This has been very dominant in the earlier part of the $20^{\text {th }}$ century but has given way to the second force in psychology called behaviorism. Currently, behaviorism is also slowly reaching its end. Slowly, holistic and more natural ways are coming to the main stream. This is the third force in psychology-the Humanistic Psychology. Many experts foresee that by the first or second decade of the $21^{\text {st }}$ century, humanistic psychology will become the dominant major force. This is because that man will slowly come to realize that the origin of bliss is in himself and so Man will turn to himself for truth, beauty, happiness, success, and achievement. Neither Freudian psychology nor Behaviorism can be of definite help in this stage.

\section{The Emergence of Islamic Psychology}

In the Islamic world, Islamic psychology as a new study approach was first introduced in 1975 by Association of Muslim Social Scientists (AMSS). More specific studies were conducted at the International Symposium on Islam at the University of Riyadh in 1978. Among the various studies, the most interesting one is the study conducted by Malik B. Badri. In his article, later published in a book entitled The Dilemma of Muslim Psychologists, ${ }^{5}$ he reveals a number of philosophical and practical defects of Western psychology, especially against the

5 Malik B. Badri, The Dilemma of Muslim Psychologists (London: MWH London Publishers, 1979). 
theory of psychoanalysis and behaviorism. His thought was then used as the starting point of the revival movement of Islamization of psychology, which in its development carries out a discipline called Islamic psychology. Although in the tradition of Islamic study the discourse on psychology has been conducted by Abdul Aziz al-Quusy ${ }^{6}$ and Musthafa Fahmi ${ }^{7}$, both are still introducing Western psychological theories to Muslims and have not tried to get closer to the values of Islamic religiosity.

The rise of Islamic psychology discourse is empirically inspired by various ideas. First, the modern Western psychology approach is seen to be very partial and artificial in viewing the human nature, bringing many crises. Second, the Western psychology theory is deemed to have denied the God factor in exploring knowledge. Third, the Qur'a and $\mathrm{H}\{$ dit as the sources of Islamic study are believed to be having many more comprehensive concepts of humanity which are different from the concept of Western psychology.

This religious idea makes the discourse on the psychology come to a point of performance more intensively. Therefore, Reflecting on and deducing the Qur'anic text needs to be conducted in this respect. Two verses from the Qur'aæ deserve citation. First is the verse (Qur'aæ 17:82) which says: "O Mankind, indeed has come to thee the lessons from thy Lord as therapy for diseases (which are) in the chest as a guide and mercy for the believers." Second is another verse (Qur'aæ 41:44), which reads: "Say, the Qur'apis the guide and the antidote for those who believe."

There are, at least, three interpretations that can be drawn from the paragraph above. First, the Qur'aæcontains a variety of knowledge and science that needs to be explored, and used as a guide as well as the base for all sciences in Islam. Second, among those knowledge and science is a method of therapy against a variety of psychological problems, which in such a verse (Qur'a 17:82) is symbolized as a disease that dwells in the chest. Third, the proof of someone's faith is marked by his or her belief in the Qur'ałas a guidance and mercy for all human activities, including activities in formulating science.

\footnotetext{
${ }^{6}$ Abdul Aziz al-Quusy, Ilmu Jiwa (Jakarta: Bulan Bintang, 1954).

7 Musthafa Fahmi, Kesehatan Jiwa dalam Keluarga, Sekolah, dan Masyarakat (Jakarta: Bulan Bintang, 1977).
} 


\section{Responses of Indonesian Muslim Intellectuals}

\section{Towards the Grand Theory of Modern Western Psychology}

The fundamental weakness of the grand theory of modern Western psychology stems from the philosophical views about human. This theory tends to determine and reduce human existence and strongly disclaims divinity values (deity) in building theory. As Badri argues, ${ }^{8}$ the grand theory of Western psychology has two fundamental weaknesses. First, Western psychologists disregard the significance of understanding the relationship between human and the Creator. Moreover, they transparently place God outside the thought of most contemporary Western psychologists and therapists. Therefore, any concepts or theories that they build are biased. Second, the logical consequence of the first view is, then, that the grand theory of modern Western psychology does not have the so-called spirit and soul. The formulation of the theory is only based on the results of studies of people who suffered psychological disorders such as hysteria and neuroses, and of experiments on animals. This in turn will result in the "dry psychology"; soulless and pathological. With the two fundamental weaknesses, the grand theory of modern psychology would have applied biases, especially when used to provide solutions and therapy of various human psychological problems.

Badri stated that the psychoanalysis theory of the determination of unconsciousness is fragile, having no solid foundation, and furthermore contrary to Islam. He further argues that the psychoanalysis theory is very much based on the "arm chair" theories which are subjective, historical hypotheses speculative, and do not have adequate scientific standards. ${ }^{9}$ In addition, the fundamental weakness of the theory of psychoanalysis lays in its philosophical views about Man and religion. Psychoanalysis views that human beings are essentially influenced by the energy of dynamic unconsciousness driven by sexual libido energy (aggressive and erotic potential). Moreover, the psychoanalysis view that one's religiosity is a symptom of neurotic disorder can be regarded as a kind of atheism, and can endanger Mankind. Ahmad Ibrahim Syauqi argues that psychoanalysis

\footnotetext{
${ }^{8}$ Malik B. Badri, Dilema Psikologi Muslim (Jakarta: Pustaka Firdaus, 1996), pp. 4-5.

${ }^{9}$ Ibid., p. 18.
} 
theory has distorted the truth, because it is built on the wrong basis, totally denying the existence of God. ${ }^{10}$

The fundamental weakness of stimulus-response behaviorism theory is that it reduces human existence as to consider human as robot or inanimate objects that can be formed and controlled at will. ${ }^{11}$ Human is seen to have a neutral image with no freedom of action and potential. They cannot develop and do the activities unless with stimuli from the environment surrounding them. Such views clearly underestimate human existence, and are therefore contrary to the principles of Islam that place humans as having innate nature.

Humanism as another theory, despite having a more advanced view of human, in reality, also has many weaknesses. The fundamental weakness of the humanistic stream is that it is too optimistic on humans, overvaluing the role of human and neglecting the existence and role of God. Humanistic theory is eventually caught up in the psychology insights that are too antropho-centric, putting humans at the center of all experiences and relations as the main determinant of all events and activities. Based on this reason, the human in humanistic view has the attributes of self-determining beings as well as the center of relatedness. ${ }^{12}$

Hassan Langgulung, an Indonesian psychological scholar, criticizes the grand theory of modern Western psychology. ${ }^{13}$ First, all the ideology of modern Western psychology is not really a soul review, but a study of the effect of the soul, namely the behavior. Western psychology does not at all discuss what the soul is, whether or not there is soul and where they come from. Therefore, Western psychology is more accurately classified as behavioral-science and not the science of the soul. Further criticism is oriented towards the origin of human nature. Psychoanalysis describes humans as being always responsive to the needs; controlled by impulses from within, including libido or sex drives. Behaviorism is over positioning human when

\footnotetext{
10 As quoted in Fuad Nashori, Membangun Paradigma Psikologi Islami (Yogyakarta: Sipres, 1994), p. 40.

${ }^{11}$ Raymond J. Carvisi (ed.) Encyclopedia of Psychology (2nd Edition, Vol. 1), pp. 149-165.

12 Nashori, Membangun Paradigma, pp. 77-80.

${ }^{13}$ Hasan Langgulung, Teori-Teori Kesehatan Mental (Jakarta: Pustaka al-Husna, 1996), pp. 310-311.
} 
studying human behavior. This is because it bases its study of human behavior on scientific method, controlling their behavior.

\section{Islamic Psychology and the Islamization of Sciences in Indonesia}

The debate about the criticism toward the weaknesses of Western psychology and the search for paradigm of Islamic Psychology has also become the concern of Muslim scientists and scholars in Indonesia. This debate stems from the rampant Islamization movement of sciences, which subsequently enters the area of psychology. Among the figures who can be considered as pioneers in Islamization of science in Indonesia is Hidayat Nataatmadja and AM Saefuddin. Both argue that in order to minimize the bias of Western grand theory of science, Muslim scientists must construct theories of science by using the paradigm of revelation; with the Qur'a and Sunnah as main references. In his book entitled Menegakean Jiwa Agama Dalam Dunia Islam (Enforcing Religious Life in the Muslim World), Nataajmadja particularly expresses his optimism that Islam would bare a new paradigm in science. ${ }^{14}$

From the debate about the Islamization of Sciences, there are efforts among Indonesian Muslim scientists to further study psychology, and encourage the development of the Islamization movement of psychology. The movement got a great response from some psychologist in Indonesia. Many scientific papers have been produced to examine various psychologies from an Islamic perspective, such as one by Hanna Djumhana Bastaman. Bastaman's paper outlines his views about Islamic psychology, wich are later published in a book entitled Intregasi Psikologi Dengan Islam: Menuju Psikologi Islami (Intregation of Psychology and Islam: Towards Islamic Psychology). ${ }^{15}$ In his book Membangun Paradigma Psikologi Islamito (Building the Paradigm of Islamic Psychology), Fuad Nashori extensively expresses his ideas about Islamic psychological thought in both global and national scale. In addition, in describing his thoughts on psychology, he also

\footnotetext{
${ }^{14}$ Hidayat Nataatmadja, Menegakkan Jiwa Agama dalam Dunia Islam (Bandung: Risalah, 1983).

${ }^{15}$ Hanna Djumhana Bastaman, Integrasi Psikologi dengan Islam: Munuju Psikologi Islami (Yogyakarta: Pustaka Pelajar, 1983).

16 Nashori, Membangun Pradigma.
} 
writes an article entitled "Psikolog Islami: Sebuah Perspektif" "Islamic Psychology as A Perspective") in which he reveals why it is necessary to build an Islamic psychology. ${ }^{17}$ For him, there are, at least, two fundamental reasons in this regard. First, and foremost, is that Islam has its own views about people, which can be extracted from the Qur'a and Sunnah. Second, the modern Western grand theory of psychology is in crisis and biased, thus requiring alternative thinking as solution.

Audith M. Turmudzi presents a number of ideas in his work entitled "Kemungkinan Membangun Psikologi Qur'ani" ("The Possibility of Developing Qur'anic Psychology"). ${ }^{18}$ Through this scientific work, Turmudzi reveals that the streams of psychology (particulary psychoanalysis and behaviorsm) are not satisfactory in explaining the concept of 'human'. Therefore, he argues that Muslim scientist should have tried to build a human concept based on the Qur'ał. Turmudzi also recommends that all the exiting psychological theories need to be assessed and verified through academic and scientific dialogs and should openly embrace the principle of academic communality. Budhi Munawar Rahman also writes an article entitled "Situasi Eksistensial dan Realisasi Diri: Psikoanalis Pasca Freudian dan masalah Spiritual" ("Existential Situation and Self Realization: Post Freudian Psychoalaysis and Spiritual Issues"). ${ }^{19}$ Similarly, in this work, Rahman also offers a concept of existential humanistic psychology. According to Rahman, the new psychoanalysis developed by Erich Fromm could be the first step toward Sufism, which is a step into the world of mystical experience. In addition, in his article "Kerangka Dasar Psikologi Islami" ("The Framework of Islamic Psychology"), ${ }^{20}$ Arif Wibisono Adi also states the importance of understanding the nature of rational-objective, and developing an intuitive-subjective method. As a result, the understanding human psychology can be done in a comprehensive and cumulative through Islamic view.

\footnotetext{
${ }^{17}$ Ibid., p. xxi.

18 Audith M. Turmudhi, "Kemungkinan Membangun Psikologi Qur'ani,” in Ibid., pp. 11-19.

${ }^{19}$ Budhi Munawar Rahman, "Studi Eksistensial dan Realisasi Diri: Psikoanalisis Pasca Freudian dan Masalah Spiritualits," in Ibid., pp 19-27.

20 Arif Wibisono Adi, “Kerangka Dasar Psikologi Islami,” in Ibid., pp. 27-35.
} 
Another series of Indonesian Muslim intellectuals play also an important role to the development of Islamic psychology discourse in Indonesia. Those scholars include Sukanto MM, Sofia Retnowangi, Ahmad Salim Sungkar, Djamaludin Ancok, and Subandi. They do generally not only provide a critique of Western psychology theories, but also try to offer ideas for the development of psychological theory that can be adaptive to the values of Islamic teaching.

\section{Crafting Religious Anthropocentrism as a Feature of Islamic Psychology}

Considering the various biases and crises of the grand theory of modern Western psychology, the theory of Islamic psychology is developed as an alternative psychology. It is built and based not only on empirical-positivistic paradigm (as in the theory of psychoanalysis and behaviorism which tend to be deterministic and inhumanistic) and on empirical-humanistic paradigm (as humanistic psychology that tends to be too anthropo-centric), but also refers to religious spiritual paradigm, the source of which are taken from the spirit of God's revelation.

By making anthropo-religious centric paradigm as a foundation of thinking in constructing psychology theory, the theory of Islamic psychology expects that psychological theories could be developed in such away that it understands and places the human in proportion, especially in relation to the Creator of this universe. That human have extraordinary intellectual capacity with broad freedom and that human behavior is crucial in every event in social life must be admitted philosophically, empirically and religiously. Moreover, the Qur'aæitself has explicitly introduced that human is the representative of God on earth (Qur'a 33:72), and is perfectly formed (Qur'a 95:4), has the freedom for action (Qur'a 13:11), and has the gift of knowledge (Qur'a 2:31-4). All of these are parallel with the humanistic view. However, this does not mean that the Islamic concept about human is anthropo-centric as the concept of humanistic ideology argues, since anthropo-centric view would be very easy to provide opportunities for people to make itself as "the sole determinant of a sovereignity" and "omnipotence" in the human level. Furthermore, if the concept of anthropo-centric becomes a strong inspiration for psychological theory construction, it certainly would exclude and deny the existence of transcendental relationship between Man and God. Moreover, other 
aspects such spirit and metaphysical relationships between human beings (creatures) to God (Creator) are excluded from the scientific psychological area. ${ }^{21}$

Islam does not reject the anthropo-centric view. That is why the message of God is linked to the creation and to the inauguration of human as khalifor fi al-ardfor the representative of God on earth (Qur'a 2:30). This deserves an understanding which develops two meanings, namely: the inaugural statement that unlicenses Man (A $\nless a m$ ), as the khalifor firl-ard can be understood as a manifestation of efforts to raise the dignity of human because of various advantages compared with other creatures. This kind of understanding can be defined as being anthropo-centric. In addition, such a verse should also be understood that the Man is a creation of God among many other creatures. The position of Man as a creature of God with the obligation to worship Him (Qur'a 51:56) indicates that the meaning of human existence must be sought from his relationship as human with the Creator. This understanding leads to the development of basic principles conveying Allałas the only God (ta`abbud), the One to rely on (tawakkul), the One to ask for hope and bet (raja $>$ and the One to whom human will be back to (ruju> or Inalah). This way of understanding can be interpreted as a theo-centric, or more explicity God-centric. Thus, it is clear that in Islam the concept of psychological perspectives does not only rely on the concept of theo-centrism thinking but also on the integration of Man and God. Such integration is the key view of anthropo-religious-centric paradigm.

Developing psychology based on religious anthropo-centric paradigm does not mean constructing a psychological theory departing from zero, but still takes the strength of Western psychological theory which has been tested with the Islamic concept of texts contained in both the Qur'a and Hadith. In other words, the theory is more directed to the framework of the development of so-called Islamic values-based psychology, which more operationally provides greater emphasis on the aspects of axiology than ontology and epistemology.

Operationally, the effort to construct the theory of psychology based on the character of anthropo-religious centric takes three

${ }^{21}$ Ibid., pp. 84-85. 
patterns. ${ }^{22}$ The first pattern is to formulate the concept of humans by directly basing themselves on the Qur'aæand Hadit. This can be done through understanding the thematic terms in the Qur'a $\gg$ and Hadi including nafs (will), insane (human), bashar (Man), al-nas łhuman being), fitrah (purity), ruf(soul), qalb (heart), and 'aql (mind). These terms, as others in the Qur'a and H\{dith, have their own meaning and are multi-dimensional. 23 Therefore, to gain an understanding of human concepts comprehensively, multi-aspect studies are needed. The second pattern is to explore the Islamic world view on humans through the depth and breadth of classical and modern Islamic thought. Muslim intellectuals from classical periods such as $\mathrm{Abu} \gg \mathrm{Bkr}$ al-Ra $>$ Ibn Sifha>al-Ghazal $>$ and Ibn Qayyim al-Jauzipah already devoted their energy to understand people with different formulations. In contemporary periods, there are scientists trying to understand people with different derivations, such as Mohammad Iqbal, Ali Shariati, and Murtadha Muththahari. The third pattern is by synthesizing modern Western psychological views and the Islamic concept of Man. The pattern of modern science becomes an inspiration to examine the same issue in view of the Qur'a and H\{dił, as done by Muhłmmad 'Uthma Najæti, Badri, ${ }^{25}$ and Sukamto MM.26 Najæti Islamic psychological theory elaborates the views of the Qur'a and H\{dit of psychological terms, emotion, and psychotherapy. The third pattern is characterized by the thought that all ideas in psychology are based on the insights from the Qur'a and $\mathrm{H}\{$ dit that are relevant with terms of modern psychology.

As a scientific discipline, the development of Islamic psychology must be supported by scientific methods. Research methods used is

22 Fuad Nashori, Psikologi Islami; Agenda menuju Aksi (Yogyakarta: Pustaka Pelajar, 1997), pp. 24-25.

23 M. Dawam Rahardjo, Ensiklopedi al-Qur'an: Tafsir Sosial Berdasarkan Konsep-konsep Kunci (Jakarta: Paramadina, 1996), p. 58.

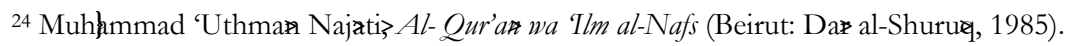
See also Idem, al-Hádi al-Nabawi $¥ a$ Ilm al-Nafs (Beirut: Daæal-Shuruథ, 1985).

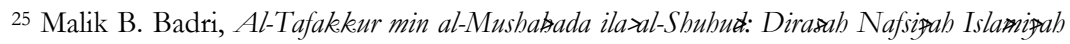
(Kuala Lumpur: International Islamic Universityof Malaysia (IIUM), 1987).

${ }_{26}$ Sukanto MM, Nafsiologi: Refleksi Analisi Tentang Diri dan Tingkah Laku (Surabaya: Risalah Gusti, 1996). 
basically the same as the method of psychological research in general. However, when refering to the spiritual-religious dimension, or relating to the nass $\}^{3}$ the texts of the Qur'a and Hadi are needed. Djamaluddin Ancok, in this case, suggests that in addition to the experimental method, observation, questionnaires, interviews and phenomenological reflections are used to construct psychology. Therefore, sense, ratio and intuition can be used as a tool. ${ }^{27}$ Noeng Muhajir offers conceptual-reflective-probabilistic-tentative methods. ${ }^{28}$ Hanna Djumhana, citing the opinion of Fred Kerlinger, argues that in efforts to develop an Islamic psychology, other methods such as the method of authority and the method of intuition can be used in addition to the method of science.

\section{Conclusion}

Psychology with anthropo-religious centric pattern is an attempt to construct spiritual-religious psychology or Islamic psychology. Empirical-positivistic paradigm and empirical-humanistic paradigm used as the foundation of the construct of modern psychology have raised the popularity of modern Western psychological theory. They have spawned psychological theories in the spirit and mind (the mode of thought) of liberal and secular Western culture, however. Therefore, there are many biases within modern Western psychological theories when applied to find an alternative solution to the problems of human psychology in different cultures, especially in the context of Islamic culture.

This reality opens an awareness of Muslim scientists to develop theories of humanistic psychology with spiritual and religious values. For this purpose, there is a need for new paradigm devoted as a basis to develop a theory of psychology that in addition to its reference toward the anthropo-centric paradigm, it also refers to the religiousIslamic values, theo-centric or God-centric.]

27 Djamaluddin Ancok and Fuad Nashori Suroso, Psikologi Islam: Solusi Islam atas Problem-Problem Psikologi (Yogyakarta: Pustaka Pelajar, 1995), p. 134.

${ }^{28}$ Noeng Muhadjir, "Metode Penelitian Psikologi Islami” (Paper presented at National Conference on Islamic Psychology, Surakarta, 1994), p. 4. 


\section{Bibliography}

\section{Books and Articles}

al-Quusy, Abdul Aziz. Ilmu Jiwa. Jakarta: Bulan Bintang, 1954.

Ancok, Djamaluddn and Fuad Nashori Suroso. Psikologi Islam: Solusi Islam atas Problem-problem psiklogi. Yogyakarta: Pustaka pelajar, 1994.

Badri, Malik B. The Dilemma of Muslim Psychologists. London: MWH London Publishers, 1979.

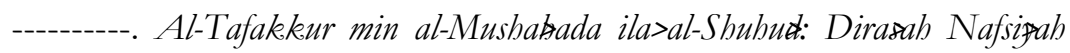
Isla rajizh. Kuala Lumpur: International Islamic University of Malaysia (IIUM), 1987.

--------. Dilema Psikologi Muslim. Jakarta: Pustaka Firdaus, 1996.

Bastaman, Hamna Djumhana. "Dimensi Spiritual dalam Teori Psikologi Kontemporer.” Ulum al-Qur’an, No. 4 Vol. V, 1994.

-------. Integrasi Psikologi Dengan Islam: Munuju Psikology Islami. Yogajakarta: Pustaka Pelajar, 1983.

Carvisi, Raymond J. (ed.). Encyclopedia of Psychology. $2^{\text {nd }}$ edition, Vol. 1.

Descartes, Rene. Descartes: Philosophical Letters. trans. and ed. by Anthony Kenny. Oxford, Clarendon Press, 1970.

Fahmi, Musthafa. Kesehatan Jiwa dalam Keluarga, Sekolah dan Masyarakat. Jakarta: Bulan Bintang, 1977.

Heil, John (ed.). Philosophy of Mind: A Guide and Anthology. Oxford; New York: Oxford University Press, 2004.

Langgulung, Hasan. Teori-teori Kesehatan Mental. Jakarta: Pustaka AlHusna, 1986.

Muhajir, Noeng. "Metode Penelitian Psikologi Islami." Paper presented at National Conference on Islamic Psychology, Surakarta, 1994.

Najał>Muhłmmad 'Uthmaæ. Al-Hadid al-Nabawi Beirut: Daßal-Shuruథ, 1989.

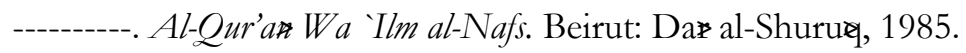


Nashori, Fuad. Membangun Paradigma Psikologi Islami. Yogyakarta: Sipres, 1994.

--------. Psikologi Islami Agenda Meniju Aksi. Yogyakarta: Pustaka Pelajar, 1999

Nataatmadja, Hidayat. Menegakekn Jiwa Agama dalam Dunia Islam. Bandung: Risalah, 1983.

Raharjo M. Dawam. Ensiklopedia Al-Qur'an: Tafsir Al-Qur'an Berdasarkan Konsep-konsep Kunsi. Jakarta: Paramadina, 1996.

Sukamto MM. Nafsionologi: Refleksi Analisis tentang Diri dan Tingkablaku. Surabaya: Risalah Gusti, 1996

Westland, Gordon. Current Crises of Psychology. London: Heinemann Educational Books Ltd., 1978.

Yolton, Jean S. John Locke: A Descriptive Bibliography. Bristol: Thoemmes Press, 1998. 